\title{
Larichos in the Brothers Poem: Sappho Speaks Truth to the Wine-Pourer
}

\author{
Eva Stehle
}

We now have a new poem by Sappho on the subject of her brothers, previously attested only by two fragmentary poems and several testimonia. ${ }^{1}$ The testimonia report that Sappho mocked the first brother, Charaxos, a merchant sailor, for spending his earnings to free a courtesan named Rhodopis or Doricha and that she praised the second, Larichos, who poured wine at the town-hall of Mytilene. ${ }^{2}$ The new poem mentions both brothers, but not for the specific activities that the testimonia describe. It therefore gives substance to the idea that there was a series of 'brothers poems' involving Charaxos and Larichos. ${ }^{3}$ It also opens a window on familial gender dynamics from a woman's perspective. This is an exciting new aspect of Sappho's poetry.

The first question is whether we should read the poem biographically: did Sappho compose this poem as her response to an actual situation at a particular moment? Our approach to reading the poem depends on the answer. Since Charaxos in this poem is like the merchant seaman in Herodotus and the 'brother' in poem 5 whose return is envisioned-and since he has no recorded activities apart from coming home after trading abroad (and buying a courtesan's freedom) - he seems to be a type. ${ }^{4}$ His role reflects what must have been

1 I want especially to thank Dirk Obbink not only for bringing us these papyri but also for patiently answering my questions about them. I also thank André Lardinois for organizing the panel and co-editing this volume, Joel Lidov, Diane Rayor, and Deborah Boedeker for helpful comments, Glenn Most for asking a question that I needed to answer, and Anton Bierl for serving as co-editor.

2 Larichos: Ath. 10, 425a (= test. 203a); schol. Il. 20.234 (also test. 203c). The second cites Sappho as saying that it was the custom for good-looking aristocratic youths to pour wine. For Charaxos see note 4 .

3 A third brother is mentioned in P. Oxy. 1800 fr. 1 lines 1-35 (= test. 252), where his name is restored as ['Ep]! [rvıov, and in Suda C 107 s.v. 'Sappho' (= test. 253), where his name is given as Eurygios. Nothing is known about Erigyios.

4 Hdt. (2.135) tells the story of Charaxos buying the freedom of Rhodopis. Test. 252 and 254 refer to this episode. Two of them, P. Oxy. 1800 fr. 1 lines 1-35 and Ath. 13, 596bc, give the name Doricha for the courtesan.

(C) EVA STEHLE, 2016 | DOI: 10.1163/9789004314832_014

This is an open access chapter distributed under the terms of the Creative Commons Attribution-

Noncommercial 3.o Unported (CC-BY-NC 3.0) License. 
a common experience for the women of Lesbos, awaiting the next homecoming of the men on whom their families depended. Larichos does not appear in Sappho's previously-known poetry, but given that his role in this poem is compatible with his being young, attractive, and at home in the symposium, as the testimonia report, he is probably a type as well. The two "brothers" then represent different aspects of the life of the prosperous class of Lesbos, with its symposium culture of leisure and its mercantile adventuring over the sea. ${ }^{5}$

Since they appear to be types, I do not think that this poem can be read as biographical. Sappho may or may not have had brothers, but these figures have at a minimum been abstracted from real relatives. Similarly, one might note that in the only mention of her own mother (98) Sappho portrays her as recommending simple adornment for women's hair in contrast to the luxurious Lydian mitra that seems to be the current fashion. Thus she too could be a type, one representing a now-lost way of life, less driven and wealth-seeking. Certainly Sappho's attitude toward riches in this poem is aligned with hers. ${ }^{6}$ However, we would need more passages mentioning her to see whether that really is her role.

Likewise, the first-person voice in the "personal" poems is a creation of the poet. Perhaps I should call this figure "Sappho" with quotation marks, but I also do not want to suggest that the speaker is a fiction only. That Sappho the poet reflected on her life and society by representing herself in relationship with others seems to me to emerge from her themes, which combine realia like festivals and dress with scenarios depicting women's emotional experience in a male-dominated culture. The continuity between the persona and the poet gives Sappho's poetry its power, for her dramatic narratives distilled those experiences and expressed them as her own to audiences that knew her. ${ }^{7}$ So I

5 See Raaflaub in this volume on some kinds of trade being compatible with elite status. He points out that one shipload could bring tremendous riches in this period.

6 Kurke (1992) 96 describes both Sappho and Alcaeus as claiming allegiance to an elite lifestyle through their use of áßpós ('luxuriant') and other forms of the stem. For Sappho, she observes, it represents 'a certain sensuality'. Unfortunately, the most significant line of Sappho's on the subject (58.25-26), 'And/but I am fond of $\dot{\alpha} \beta p o \sigma \dot{v} \alpha \alpha$...', has no larger context to show us what it is paired or contrasted with, although the quotation containing it goes on to say something like, 'and erōs has allotted me the light of the sun and the beautiful'. So Sappho deeply enjoyed the sensuous and alluring but did not necessarily embrace wealth as power. Kurke (idem: 101, n. 43) thinks she was ambivalent about it.

7 Morrison (2007) 41 speaks of the 'pseudo-intimacy' of Sappho's (and Alcaeus') poems in explaining why audiences outside the original one would find them attractive, and (48) comments that in archaic lyric the narrator becomes a subject for narration. 
will not use quotation marks in referring to the speaker as Sappho but do stress that she is presenting a fictionalized self. And now that we have the 'Brothers Poem' we can see another facet of her fiction, a woman commenting on the behavior of male relatives.

These considerations frame my approach to the poem. But they do not in themselves generate a reading of the poem. And at first glance it seems dull. Gautier Liberman, for instance, calls it a 'poème assez prosaïque' that 'contient des signes potentiels de composition hâtive', although he praises some aspects of it. ${ }^{8}$ M.L. West had a similar reaction. ${ }^{9}$ But the problem is not just poetic quality; it is hard to make any sense of the train of thought. No logic seems to connect the successive stanzas: you should not keep saying that Charaxos will come with wealth; you should send me to pray (but not for wealth); and (to pray) that Charaxos find us in good shape, and let's entrust the rest to the gods, for good weather can spring up suddenly; the gods give wealth to whomever they wish; if Larichos becomes a man we will be released from sorrow. Sappho seems to be unhappy with two different people, criticizing one for a mental fault and commenting that the other needs to change his behavior, with bits of conventional wisdom about fortune in between. ${ }^{10}$ Her major poems are tightly constructed and, when we can tell $\left(1.25,16.15^{-20}\right.$, maybe 31.17 and 96.18-20), they bring the train of thought to a close in a stanza that adds a new twist and simultaneously caps the whole logical sequence. ${ }^{11}$ This new poem seems conspicuously to fail at doing that.

I will argue that, on the contrary, the poem is a good example of Sappho's poetic style and does have a striking shift of perspective at the end that simultaneously completes the whole train of thought. What makes it snap into focus is taking the addressee to be Larichos. The addressee is clearly a family member who would have a stake in Charaxos' success. It seems likely that the addressee was male, since Sappho asserts that this figure should 'command' her to go pray

$8 \quad$ Liberman (2014) 8.

$9 \quad$ Reported by Obbink, ch. 2, this volume, citing an email from M.L. West to Mary Beard before publication of the discovery in the Times Literary Supplement.

10 Obbink (2014) 35 (and cf. 45) suggests that once Charaxos has brought riches home, Larichos will be able to take his place as a wealthy aristocrat.

11 For new support for the view that 16.20 is the end of that poem see Burris, Fish, and Obbink (2014) 5. The end of poem 31 is missing, but if 17 is the first line of the last stanza then all must be dared / endured' is the new twist on the thought that the man seems like a god and Sappho seems to herself to be near death. Poem 96 plausibly ended at 20, since the following stanza is in asyndeton and on a different subject, although the papyrus does not indicate as much. 
to Hera. ${ }^{12}$ A male family member would have the authority to direct her. She could have urged him to go himself, but she recognizes that he would find it easier (given his inaction so far) and perhaps more appropriate to send her. What little evidence there is suggests that women were major celebrants at Hera's shrine at Messon. ${ }^{13}$ Moreover, there is a hint that Larichos' name stood in the largely missing first stanza, for the letters $\Lambda \mathrm{A}$ are preserved in line 3 . They most likely formed the third syllable of the line, so the full name would fit the meter if a word beginning with a consonant (or, in the case of the vocative, two con-

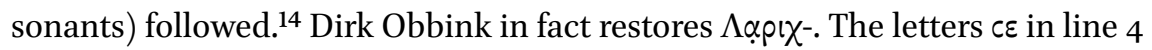
are read as the pronoun 'you' in the accusative, so the exiguous remains are compatible with the idea that she addressed him there.

But the most compelling reason for assuming that Larichos is the addressee is that he is the subject of the final stanza. A poem's addressee should have something to do with the poem, and the last stanza should be connected to what has preceded. If Larichos is addressed in the first stanza then the entire poem concerns his response to family pressure arising from Charaxos' absence; it depicts Sappho's (fictional) attempt to persuade him to take some responsibility. However, most of the scholars who have dealt with the poem resist this solution because they see the reference to Larichos in the third person at the end as ruling it out. Camillo Neri adds that $x \alpha \mu_{\mu} \mu^{\prime}$ in line 13 will then include Larichos whereas $x \alpha \ddot{\mu} \mu \mu \varepsilon c$ in line 21 will exclude him, which he finds unacceptable. ${ }^{15}$

For my part, far from seeing these features as a problem, I think they are one source of the poem's power and drama. The addressee is a rhetorical figure, the foil for Sappho's play of brother-sister relations. ${ }^{16}$ The actual audience (on which more below) hears her trying to persuade him and deduces his position from what she says. When she ceases to speak to him in stanzas five and six, the audience can hear the change in her attitude and construe the development

12 Lardinois, in this volume, also proposes a male addressee, Sappho's third brother, Eurygios.

13 See Burris, Fish, and Obbink (2014) 10 for an expanded text of poem 17 that mentions (1314) 'a throng of maidens ... and women' addressing Hera; the first-person-plural verb in 11 must belong to this throng. On $5^{-6}$ the authors suggest that the performance of this song could have been at the festival of Hera, Zeus, and Dionysus celebrated by women at Messon, to which Alc. 13ob.17-20 refers.

14 See West (1982) 17 n. 31, 18 for Lesbian poets' treatment of double consonants that are sometimes treated as single in other poetic traditions.

15 Neri (2015) $5^{8}$ n. 32. Kurke (personal communication) similarly objects.

16 Peponi, this volume, also stresses the sister-brother relationship but sees the poem as a vignette of daily life. 
of their encounter accordingly. ${ }^{17}$ On hearing the third person in stanza six it realizes that from her new position Sappho is explicating reality not just at the cosmic level but also at the human level of Larichos' relationship to the family ( $\alpha \dot{\alpha} \mu \mu \varepsilon c, 21)$. It also realizes that this perception is what has been behind her tactful attempts to persuade him all along and that the $x \alpha$ a $\mu \varepsilon \varepsilon$ here may exclude him if he does not act to join them. This revelation is the new twist that simultaneously caps the whole logical sequence. In sum, the poem is not disjointed or aimless but a miniature drama. There is a suggestive, though partial, parallel in poem 96 to Sappho's change of perspective here, which I will examine when I get to that point in my detailed discussion below.

A number of the scholars who have written on the Brothers Poem identify the addressee as Sappho's mother, as Dirk Obbink tentatively suggested in the original publication. ${ }^{18}$ Leslie Kurke further argues that verb $\theta p u \lambda \varepsilon i v$ (usually translated 'babble', but see below) is too rude to use to a man's face-which means also dismissing the remark of Herodotus that Sappho 'mocked' Charaxos for his involvement with the courtesan. ${ }^{19}$ Anja Bettenworth on the contrary thinks that Sappho would hardly use $\theta p u \lambda \varepsilon i v$ in speaking to her mother, but she

17 One striking characteristic of Sappho's poetry is her sudden shifts of speaker and/or perspective, as in frs. 1, 16 (where Helen is object then subject of desire), 94 (if Sappho speaks line 1), 96 (on which see below).

18 Obbink (2014): 41. West (2014) 8 and Ferrari (2014) 4 approve of the idea early on. The letters that follow $\Sigma \mathrm{E}$ in the fragmentary first stanza are MA. So West (2014) 9 further says it is tempting to supplement them as some form of $\mu \dot{\alpha} \tau \eta \rho$ but that the space before the extant letters is not large enough to contain two syllables, which would be necessary since the A of $\mu \alpha \dot{\alpha} \eta \eta p$ is long. However, Obbink $(2015 b) 2$ takes it up as a plausible suggestion, disagreeing with the view that there is not enough space for two syllables and supplementing with the vocative $\mu \hat{\alpha} \tau \varepsilon \rho$. It is important to understand that the idea that the mother must be the addressee preceded the supplement and is its only justification. So when Obbink says that the supplement adds support for the hypothesis that the person addressed is the mother he has it backwards. A quick look in LSJ produces as possibilities (with a short $\alpha$, the easier view), e.g., some forms of the aorist of $\mu \alpha \nu \theta \alpha \nu \omega$ (perhaps with se and infinitive), some

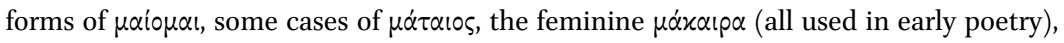
and so on. My point is not that any of these is especially plausible but that $\mu \hat{\alpha} \tau \varepsilon \rho$ is no more so.

19 Kurke, this volume. On Herodotus she cites Lidov (2002). But the name 'Charaxos' comes from Sappho's poetry, and it is more economical to suppose that Sappho 'mocked' Charaxos in a poem (whether or not she actually named a courtesan) that was then perceived as fodder for a tale of courtesan seduction than to suppose that the name Charaxos (but not Larichos) was taken up and attached without motivation to a courtesan story in a comedy about Sappho's sexuality. The idea that Herodotus was drawing on comedy is itself fragile. 
suggests a different female, a slave attendant of Sappho's, as addressee. ${ }^{20}$ There are other suggestions, too: Camillo Neri, who argues that it is the mother, gives a list of eleven candidates. ${ }^{21}$

My objections to taking the mother as the addressee are that it does not illuminate anything in the poem; that instead it makes the criticism of the addressee in the second stanza trivial and the addressee's resistance to sending

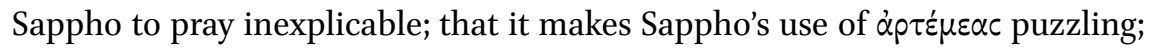
that it requires reading the last stanza as an optimistic prediction in the face of its dubious tone; that the addressee's focus on the full ship does not sort with the advice Sappho attributes to her mother in poem 98, her only mention of her mother (see above); that Sappho very probably used a past tense in referring to her, which suggests that she is not to be thought of as a participant in Sappho's family dramas; and that $\theta p \dot{\lambda} \lambda \eta c \theta \alpha$ is not language that Sappho would depict herself using to her mother. ${ }^{22}$ Identifying the mother as the addressee seems to have been arrived at by a process of elimination among known or proposed figures linked to Sappho's biography rather than by thinking about the poem. ${ }^{23}$

Another issue at work here is lack of attention to the question about who the actual audience is, as opposed to the addressee. Elsewhere Sappho clearly addresses someone who is not her actual audience, for instance in poem 31, whose addressee is sitting beside a man, talking and laughing with him, so we should see these as separate. ${ }^{24}$ Kurke interestingly refers to this poem being set in 'space-off', a publically-inaccessible location in which women speak to each other, but does not say what relationship she thinks this internal setting had to the actual audience. ${ }^{25}$ Yet in addition to the addressee we must take into account the audience to whom Sappho presented her poem, for

20 Bettenworth (2014) 15-16. Nünlist (2014) 13 also objects to it because of the derogatory tone of $\theta p \dot{\nu} \lambda \eta \in \theta \alpha$ and the implication that the addressee cares mainly about the cargo.

$21 \quad$ Neri (2015) 57-58.

22 Neri (2015) 59-6o gives the latest and most extensive argument for the mother as addressee. But he glosses over the first problem mentioned by suggesting ( 56 and passim) that this poem is a prelude to a poem of prayer and the second problem by suggesting (62) that Sappho really means 'let us go to pray'. He proposes that the difficulty being discussed in the poem is that there is no man in the house to take charge (an idea with which I agree) but argues (59) that therefore all the men of the family are excluded as addressees, ignoring the possibility that Sappho is speaking to one whom she wishes would take charge. For the past tense in fr. 98 see Voigt app. crit. ad loc.

23 See Obbink (2014b) 41; cf. Neri (2015) 59-6o, who does the same with a larger field of possibilities.

24 Archilochus does the same, e.g., in epodes addressed to Lykambes, frs. 172 and 173 .

25 Kurke, this volume. In such a space a sister could also speak to a brother. 
she is speaking to them in a different way. As for who that was, the most plausible social context for regular performance of her poems is a group made up of sympathetic women from her extended family and allied families on Lesbos, a quasi-counterpart to the symposium. ${ }^{26}$ If this is right then she is in fact speaking to women in a 'space-off', and her 'us' and 'we' in the Brothers poem could notionally include some of those listening to the poem. Within such a circle she could speak freely by creating "true" fictions as a way to assess the behavior of others, negotiate relationships, and (as I have argued elsewhere) try to counter, emotionally, women's lack of control over their fate. ${ }^{27}$ Commenting on men's behavior within such a gathering was probably one of the ways women had of exerting social pressure on male family members, and such a regular audience would provide the context for an ongoing series of brothers poems - a topic that would no doubt be appreciated by her female audience.

So now let us turn to the 'Brothers Poem'. The largely-missing first stanza must have indicated the nature of the problem that Sappho and Larichos face, the situation bringing on the $\beta \alpha p v \theta u \mu i \alpha \nu$ ('heavy-heartedness') that she mentions in the last stanza. It must have concerned Charaxos' not having returned and the impact on family resources. To anticipate the analysis of the following stanzas, their logical structure consists of a repeated sequence in which Sappho first objects to Larichos' solution to the problem, and then promotes her alternative solution. This pairing of objection followed by alternative recurs four times and occupies the whole poem from line 6 to the end. Each successive pair expands the context of objection plus alternative until it lays bare both cosmic and large familial dynamics. The drama of the poem lies in Sappho's tactics as she tries to induce Larichos to adopt her solution.

Sappho begins the second stanza by identifying what is clearly the addressee's solution: 'but you always insist on Charaxos' coming with a full ship'. The verb provisionally translated as 'insist on' is the relatively rare $\theta \rho u \lambda \varepsilon i v ;$ it is worth looking at it a little more closely. In what used to be its two earliest appearances before it surfaced in the Brothers Song, Euripides' Electra 910 and Aristophanes' Knights 348, it means obsessive, repeated rehearsal in anticipation of speaking openly under the right circumstances. In the tragedy Electra uses it of herself as she berates the head of the murdered Aegisthus (909-912):

26 See Stehle (1997) $276-277,282-287$ on the setting and dynamics of Sappho's political poetry.

27 Stehle (1997) 288-311, although I would not now say that the 'circle [of Sappho's friends] was not their primary setting' (288); I would say that the songs had a function that went beyond that setting by serving also as repositories of memory for other women. 
'and certainly through every morning's dawning I never left off rehearsing ( $\theta p v-$ $\left.\lambda \circ \hat{\sigma} \sigma^{\prime}\right)$ what I wanted to say to your face if I were really to become free of my earlier fear'. What Electra describes is the opposite of babbling (the received translation), if babbling implies speaking at random: she is repeating her grievances and insults over and over as she imagines the pleasure of being able to say them to him. In her mouth $\theta$ pu $\lambda \varepsilon i v$ is descriptive of a compulsive state of mind. The Aristophanic passage uses it mockingly, referring to someone rehearsing all night in preparation for a trivial court case. ${ }^{28}$ Since these two passages are closest in time to Sappho and also poetic, they constitute the best guide for the verb's meaning in the Brothers Poem.

So, when Sappho depicts Larichos as 'always' rehearsing his line, she means that he is constantly, urgently repeating it in anticipation of saying it under the right circumstances. In his case the content of the line and the circumstances under which he wishes to say it are the same: he wants to announce truly that the ship has come in laden with goods. The verb shows that he is deeply invested emotionally in this solution but feeling pressure from the difficult situation, which he wards off by repeating this mantra whenever the problem is mentioned.

Further indicating the mantra-like quality of his line is the fact that it contains an aorist infinitive ( $(\dot{\varepsilon} \theta \eta \eta)$ rather than the expected future infinitive. As a declarative infinitive in an indirect discourse construction it would have to be translated '(Charaxos) has come', but that appears to make no sense. It has therefore been analyzed as a dynamic infinitive in a construction of willing, which my translation, 'insists on Charaxos' coming', attempts to capture. ${ }^{29}$ This

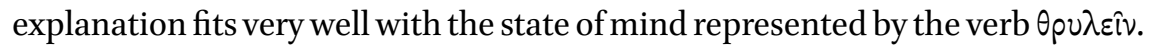
Yet if we want to press 'rehearsing' it is also possible to understand that Larichos is repeating 'Charaxos has come' over and over in anticipation of its being true. ${ }^{30}$ For him Charaxos' having come is already the answer, before it happens. With either reading of the infinitive, he is treating it as (about to become) fact, so he is clearly convinced that his solution is inevitable. And this attitude of his explains why in the rest of the poem Sappho makes an effort to discredit his

28 LSJ gives 'repeat over and over' as a meaning for the Euripides passage only, but it has the same meaning in Aristophanes. The villain Paphlagon insults the hero by saying he cannot

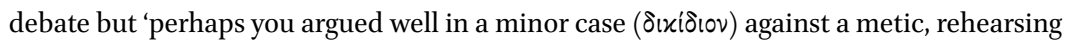
$(\theta p \nu \lambda \hat{\omega} v)$ all night and talking $(\lambda \alpha \lambda \hat{\omega} \nu)$ to yourself in the streets ..., so you thought yourself a capable speaker' $(E q \cdot 347-350)$.

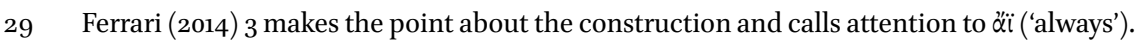
West (2014) 8 calls the infinitive 'purely aspectual'.

$30 \quad$ Neri (2015) 57 suggests this as a possible interpretation but prefers the other one. 
solution as a prelude to each of her attempts to win acceptance for her solution: he is so closed to any suggestion that he should cope with the problem in some other way that Sappho must undermine his idée fixe before she can get him to hear what she is proposing. Moreover, as will emerge, her solution is for him to step up and become active in support of the family himself, so he has a strong motive for not hearing it. ${ }^{31} \mathrm{He}$ was known as a wine-pourer at civic symposia, and we can easily deduce that his insistence that Charaxos' arrival will solve the problem stems from his wanting to prolong his pleasurable ease.

Sappho first counters his mantra by pointing out that, while Zeus and the other gods know whether that will happen, it is not Larichos' prerogative to know. With cદ̀ $\delta^{\prime} \circ \dot{v} \chi p \hat{\eta} \tau \alpha \hat{\tau} \tau \alpha$ vónc $\theta \alpha \mathrm{l}$ ('but you should not perceive this') she is saying both that he cannot know the future and that he is usurping the privilege of the gods when he claims to see what will happen. ${ }^{32}$ The pronoun c' ('you') is fronted to make the contrast with the preceding word $\theta$ ćol ('gods') explicit. Then, continuing the construction with $\chi \rho \hat{\eta}$, she urges that he send her to pray. Praying contrasts with claiming to know. If he does follow her advice, he will be admitting that he does not already know the future. So the first pairing of objection and alternative is about the kind of speech that is appropriate in the situation and the kind of action that it entails.

The second pairing appears in Sappho's proposed prayer. She includes it in indirect discourse as the two requests that he should 'order' her to make, namely 'that Charaxos arrive here guiding a ship that is safe' and 'that he find

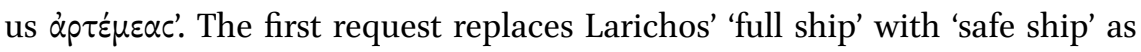
the desideratum, and also describes Charaxos as guiding the ship. ${ }^{33}$ Implied by both of these changes is criticism of Larichos for treating Charaxos as the instrument by which the wealth will be delivered. In place of cargo, she pictures Charaxos as the active one who leads his vehicle and expresses concern that they not lose this most valuable resource of man and ship.

Sappho's second prayer-request is a surprise addendum at the beginning of the fourth stanza: 'and that (Charaxos) find us $\alpha$ p $\tau \varepsilon$ ' $\mu \varepsilon \alpha c$ '. This half of the prayer, which reflects Sappho's alternative solution, shifts the focus to those at home, Larichos and the rest of the family. But to see specifically what she is advocating, we need to investigate the adjective artemēs.

31 Ferrari (2014) 4 suggests that Sappho is promoting Larichos to be the new family head.

32 Cf. Hom. Hymn Merc. 548: Apollo predicts failure for one who 'stupidly wants to find

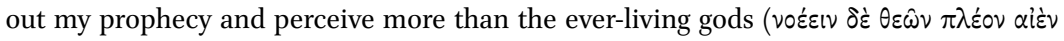

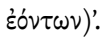

33 Nünlist (2014) 13 points out that the adjective 'safe' is not usually applied to objects rather than people, so its use here is emphatic. 
The word is very rare, known primarily from Homer. Its etymology is unknown, and its precise meaning must be deduced from its contexts. ${ }^{34}$ The two instances in the Iliad are in a formulaic line and a half that is repeated $(5.514 \mathrm{~b}-$

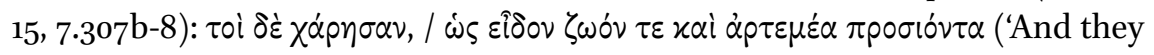

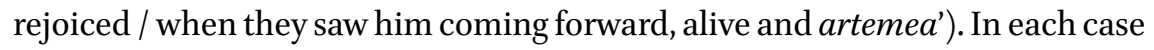
what the Trojans see is a warrior, Aeneas and Hector respectively, returning from a dire situation. Each is 'safe and sound' (LSJ's translation of artemés). But the combination of the hero's unexpectedly dodging death and his 'coming forward' (to resume fighting immediately in Aeneas' case) suggests a stronger meaning than róos ('safe'). ${ }^{35}$ In the book 5 passage, the narrator emphasizes Aeneas' recovery of self-confidence three times: in line 448 , where he says that Leto and Artemis 'were healing him and giving him glory ( $x$ v́d alvov)'; in line 513, where Apollo 'put strength ( $\mu$ źvoऽ) into his breast' as he sent him back out to the battlefield; and in line 516, where an extra half-line, 'having good strength', is added after the formula. G.S. Kirk describes this half-line as 'a unique and surely a feeble phrase', but it could be read as a gloss on artemea, a confirmation that Aeneas was visibly eager for battle. ${ }^{36}$ I therefore propose 'steadfast' or 'unshaken' in spirit as well as flesh as the best translation.

This interpretation of the meaning gives greater point to the adjective in its only appearance in the Odyssey. Here it is plural and alludes to a different kind of dire situation. Just before he leaves the Phaeacians, Odysseus expresses a wish in his farewell address to the assembled nobles (13.41-43):

\author{
$\tau \dot{\alpha} \mu$ ol $\theta \varepsilon o i$ Oj̉pavíwves

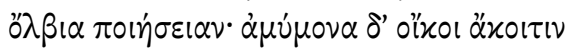

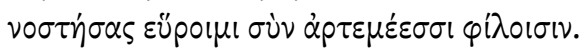

May the Olympian gods make [your gifts]

richly-enjoyable for me, and may I find my wife blameless in the house on my arrival, together with artemeessi friends.

So Kirk (1990) ad Il. 7·308-310, who says that it "clearly means something like "unharmed," the graze [that Hector has sustained] of 262 being ignored'.

In 7.307-310 the Trojans see Hector coming artemea away from his duel with Ajax, 'having escaped the strength and irresistible hands of Ajax, / and they led him toward the city,

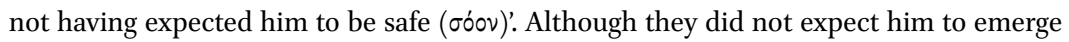
unwounded from the duel, Hector is not only 'safe' but 'unshaken', as his speech to Ajax (284-302) indicates.

36 Kirk (1990) ad Il. 5.514-516. He does remark that it shows that Aeneas is ready for action. 
Our adjective is paired here with $\alpha \mu \nu$ u $\mu \nu \nu$ ('blameless', 'excellent'), whose meaning is expanded on by Athena in a later passage, 15.14-23. There Athena warns Telemachus to go straight home, 'so that you find your mother $\alpha \mu \nu$ uov $\alpha$ in the house. For already her father and brothers call on her to marry Eurymachus ... Take care lest she carry possessions from the house against your will. For you know what sort of spirit is in the breast of a woman; she wants to make rich that house into which she weds and no longer remembers her earlier children and dear husband, now dead, or asks about them.' The wife who is not $\dot{\alpha} \mu \nu \mu \omega \nu$ transfers her loyalty away from the old house. Odysseus is hoping that his wife has remained loyal and surely wishes to find his friends steadfast in their allegiance as well. In fact the scholia on the passage offer exactly

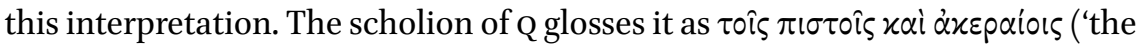
trustworthy and incorruptible ones') and explains that it derives from äp

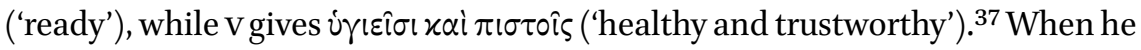
does get home, Odysseus' prime concern, up to the moment of taking revenge on the suitors, is to find out who is loyal and prepared to fight at his side and who is not.

So Sappho's second request to Hera is that Larichos along with the rest of them be steadfast in support of Charaxos (and each other). In this pair she highlights the behavior she is looking for more generally, broadening its scope from the single action of sending her to pray to an overall posture of activity on behalf of family interests. She now also locates the source of the problem on Lesbos. After her implied criticism that Larichos does not value his brother for himself, Sappho implicitly asks him (by endorsing her prayer) to recognize the importance of a politically active family's standing together. She further emphasizes mutuality—and avoids sounding critical—by using the first person plural, 'find us steadfast'.

But the very fact that she wishes to pray for the family's loyal support of Charaxos delicately raises the possibility that Larichos might not be steadfast. Given his attitude, what happens if his solution fails? René Nünlist suggests that with $\dot{\alpha} \tau \tau \dot{\varepsilon} \mu \varepsilon \alpha c$ Sappho is alluding to the Odyssey passage cited above, which would set up a parallel between Odysseus and Charaxos. ${ }^{38}$ Since Odysseus

37 Dindorf (1855) vol. 2 ad loc. See Pontani (2011) 329, 435-438 on ms. Q, which descends via z from H, pp. 208-217 on $\mathrm{H}$ ('perhaps the most important in absolute terms for a future editor of the Odyssey scholia', 217), and pp. 183-192 on the oldest ms. of the v family. Dindorf, he points out (332), often cited $\mathrm{z}$, or rather Q, because of his imperfect knowledge of $\mathrm{H}$.

38 Nünlist (2014) 13. To call it allusion perhaps assumes that Sappho had the same text we do, but Sappho's use of a rare word that expresses Odysseus' need so well could be 
appears to come home resourceless, as a beggar, he finds out perforce who remains loyal to him personally. The parallel raises the question: if Charaxos comes back empty-handed, will Larichos embrace his brother or turn against him and defect to another political grouping that can better support him? ${ }^{39}$ By outlining her prayer to him Sappho is indirectly posing that question and asking him to commit to her solution. (In this connection it is worth noting that in poem 5.5-7 Sappho expresses a similar wish for Charaxos' loyalty, also in the form of a prayer [to the Nereids this time]: 'And [grant] that he undo all the things that he did wrong, and may he become a joy to his friends and a grief to his enemies ...'.)

Each of the first two pairs objects to Larichos' solution and offers an alternative, the first one criticizing his hubristic speech and proposing prayer as an alternative, the second criticizing his attitude toward a family member and proposing a different one. The first pair points sotto voce to Larichos' dangerous hubris, while the second points in the same veiled way to danger to the family from his behavior. In her third pairing, which takes up the rest of the fourth stanza, Sappho expands the scope of the contrast again to divine influence on human life. In the first half of this pair Sappho retains the first person plural from the beginning of line 13 and uses a hortatory subjunctive clause to encourage Larichos directly to abandon his idea (13-14), 'and let us entrust

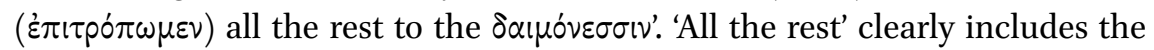
rich cargo for which Larichos hopes. But her use of the word daimones, which occurs only once or twice in her extant fragments, is surprising. Seeing the full implications of what she is proposing involves asking who these daimones most likely are.

Sappho's daimones have been taken by most scholars to mean the Olympian gods. In Homer daimōn is most frequently used, in the singular and usually by characters rather than the narrator, to designate the nameless agent of a sudden change of fortune or feeling, often for the worse, or to identify the bringer of one's fate..$^{40}$ Occasionally the daimōn can be identified with an Olympian god acting in hostile or coercive fashion..$^{41}$ In two passages it seems to be linked to

meant as a reference to him without pointing to a particular text. Nünlist also describes the adjective in the Odyssey passage as referring to the 'Unversehrtheit des sozialen Umfelds'.

39 Cf. Alc. 70. 10-11: 'Let us let go of the heart-devouring strife and battles within the family

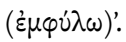

40 See LfgrE s.v. 1a, which notes that a daimōn may be called xaxós ('evil') or $\sigma \tau u \gamma \varepsilon p o ́ s$ ('hateful'), whereas a theos ('god') never is. For 'bringer of fate', see, e.g., Il. 7.291-292.

41 LfgrE s.v. 1b: Il. 3.420, where Aphrodite is called a daimōn when she is forcing Helen to go 
the Erinyes. ${ }^{42}$ The plural evidently denotes the Olympian gods in two passages (Iliad 1.222 and 6.115); however, the latter, which is very problematic, is the only place in Homer, Hesiod, or the Homeric Hymns in which the term is used of Olympian gods in relationship to humans. ${ }^{43}$ Hesiod uses the plural of minor but beneficent creatures: members of the golden race become daimones after death through the will of Zeus, 'good, above-ground, guardians of mortal humans ...

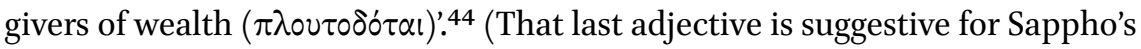
poem.) In the two epics, in short, "daimones" is neither a category nor a catchall term for divine powers. What seems to distinguish them (and Hesiodic daimones) conceptually from theo $i$ is their mode of interaction with humans: by and large daimones are not figures to whom it is beneficial (or even possible)

to Paris, and 3.166, where presumably Zeus is meant (cf. 16o); Od. 5.421, where Odysseus refers to Poseidon or some other hostile power and adds that he knows that Poseidon hates him. In Hom. Hymns the singular is used of either an Olympian or a non-Olympian

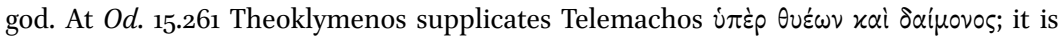
assumed that the latter noun refers to Athena, to whom Telemachus is sacrificing, but Theoklymenos has no idea who that is, so he merely uses the widest term for divine figures.

In Il. 19.188 Agamemnon says he will not swear falsely in the face of the daimōn and later swears by several divinities, including the Erinyes, 'who under the earth punish men who swear falsely' (259-260); in Od. 2.134-136 Telemachus says that various figures will give him difficulties if he sends his mother out of the house, Ikarios some of them, 'a daimōn others, since my mother will invoke the hateful Erinyes if she leaves the house'.

43 In $I l$. 6.113-115 Helenos has advised Hector to return to the city and ask their mother and the other elder women to pray to Athena. Hector then announces to the troops that he is going to tell 'the old councillors and our wives to pray to the daimones'. The word

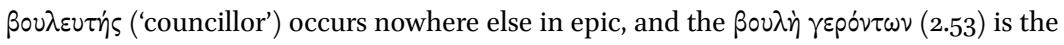

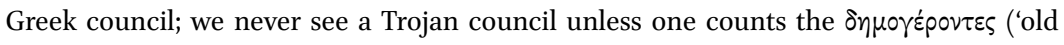
men of the city') watching from the wall in 3.149. The third passage usually cited is at best ambiguous: in Il. 23.595, Antilochus says that he does not want 'to be culpable in

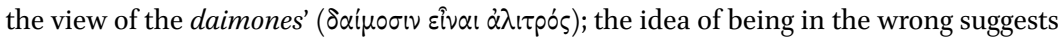
that he is thinking of avenging figures rather than Olympians. Hom Hymn Ap. 11, Hom. Hymn Merc. 381, and Hom. Hymn Cer. 338 have the plural referring to gods of the upper air, but only in Hom Hymn Ap. are the Olympians specifically designated. This passage and Il. 1.222 are not enough to support the assumption that the Olympians must be meant in Sappho.

$44 O p .121-126$. See West (1978) ad 122-123: Daimōn and theos were not explicitly distinguished until the fifth century, but Hesiod probably did not think of these spirits as theoi. Cf. Op. 249-255 for Zeus' innumerable immortal watchers over humans, Od. $17.485-487$ for theoi who similarly roam the earth observing humans. 
to pray. ${ }^{45}$ After Homer they are often subordinate to Zeus and do his bidding. ${ }^{46}$ Thus in Sappho's poem the daimones are plausibly so-named in contrast to the theoi of line 7 .

If this is indeed what Sappho means by daimones (and her meaning for daimōn in line 12 strongly suggests that it is), then the daimones are less accessible than Hera, and the verb ह̇ $\pi \iota \tau \rho \dot{ } \pi \omega \mu \varepsilon v$ ('relinquish') is in opposition to $\lambda i \sigma-$ $\sigma \varepsilon \sigma \theta \alpha \mathrm{l}$ ('pray'). ${ }^{47}$ Her point is then that Larichos should arrange prayer for those things for which one can entreat the gods and abandon his stubborn desire for what comes by arbitrary divine will. Moreover, by asking him to relinquish his fixation she is implying that it is the heart of the problem. Yet she phrases it in a positive way: she proposes that 'we' give up the idea, offering a kind of catharsis that will release him from his obsessive state. ${ }^{48}$

In the last two lines Sappho offers an image of the pleasure that catharsis

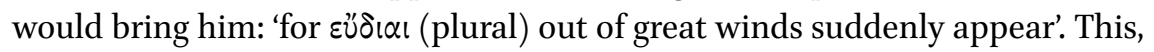
we may deduce, is the reward that he will gain by adopting her solution. In question, however, are both the meaning of eudia (this being its earliest occurrence) and its relationship to the daimones, for the clause is connected by róp ('for') to the preceding one. To begin with the meaning of eudia, it is literally 'good weather'. Sappho's statement about eudiai in the plural is a generality, however, so she must mean more than that Charaxos might have good sailing weather (and one would have to assume that great winds are blowing as she

$L f g r E$ s.v. offers 'Schicksalzuteiler' ('assigner of fate') as an overall meaning. Thgn. 341-350 begins by asking Zeus to answer his prayer and give him good to replace the bad; he then rehearses his grievances against those who harmed him and ends with 'may it be possible to drink their black blood, and may a good daimōn rush at them, and may it accomplish these things in accord with my wishes'. We could say that Theognis prays to Zeus to send an implacable daimōn against an enemy or (perhaps better) that the passage moves from prayer to a curse-like wish for vengeance. See also Burkert (1985) 180-181 on the nature of daimones. I do not want to claim that this distinction is more than a strong tendency, and it did generate its opposite. Agathos Daimon, on whom see Sfameni Gasparro (1997) 78-82, later received cult.

46 For daimones in early Greek poetry more generally and the pre-Socratic philosophers, see Darcus (1974); Sfameni Gasparro (1997) 70-71 on the two directions in which understanding of daimones moves, toward their autonomously intervening at will and toward their being subordinate to Zeus. She also discusses their relationship with fate and fortune. The term daimōn is found only once in Sappho, fr. 67a.3, with no context except a few words that suggest blame or complaint. A commentary, fr. 9oa col. II, 13, has $\delta \alpha \mu[.] \nu \alpha \theta$.

48 Cf. the opening stanza of the new fragment $16 \mathrm{~A}$ as reconstructed by Obbink in this volume: 'it is not possible for a human being to become completely endowed-with-all-that-is-good (ö $\lambda \beta(0 \varsigma)$ but it is possible to pray to have a share of good things. I recognize this for myself'. 
speaks in order to make it apply literally to him). Nor would Charaxos' having good weather in itself satisfy Larichos, for favorable sailing weather does not guarantee a good cargo, as the courtesan story shows.

For a better sense of its range of meaning, let us turn to Pindar, for whom eudia is an important metaphor. ${ }^{49}$ Two of his five uses of the word are in contexts that illuminate Sappho's poem, the second especially since eudia and daimōn occur together in it. The first, Paean 2, is helpful because the context is political rather than athletic $\left(5^{0}-55\right)$ :

50

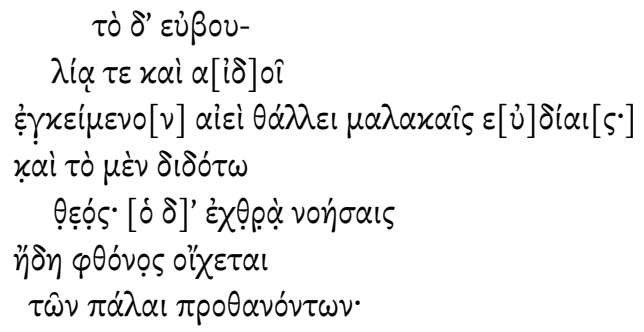

\section{That which relies}

upon good counsel (euboulia) and respect (aidōs)

always flourishes in gentle tranquillity (eudia),

and may the god grant it.

But hate-mongering envy

55 has now disappeared

for those who died long ago.

transl. RACE

Unfortunately this passage occurs right after very fragmentary lines, so the context is not clear, although, to judge from the term $\varphi$ Oóvos ('envy'), it seems to be recent civil strife. ${ }^{50}$ What is evident is that euboulia and aidōs reflect the qualities, wise practical action and respect for others, that bring eudia. ${ }^{51}$ Like the quality of being artemess, these pertain to constructive engagement, and the idea of acting for the common well-being of a group is common to both. In

49 The passages containing it, aside from the two discussed here, are Pind. Ol. 1.97-100, Pyth. 5.5-11, and fr. 109; Aesch. Sept. 792-798. Later it is used with different connotations or has its literal meaning, 'fair weather'.

5o See Rutherford (2001) 270. Stasis is the context in the four-line excerpt from Pindar quoted by Stobaeus (109).

$5^{1}$ Agamemnon uses the verb $\alpha \grave{i} \varepsilon \varepsilon \hat{\sigma} \sigma \theta \varepsilon$, 'show aidōs', in exhorting the troops to support each other in Il. 5.529-532, discussed below. 
both cases the group shares the resulting eudia. At the same time, the singers ask that the god grant it, just as Sappho hopes to pray that Charaxos find them artemeas. Eudia requires both human action and divine support.

The other, a passage in Isthmian 7 , has a deeper thematic connection with Sappho's poem, for it involves a family, eudia emerging from a storm, and eudia contrasted with the action of a daimōn..$^{22}$ This last will cast light on their relationship in Sappho. Early in the ode the singers praise the victor, Strepsiades, and add that he has given a share of his victory to his like-named uncle, who was killed in battle. That leads into an extended encomium of the uncle, culminating in an apostrophe to him. The younger Strepsiades' victory evidently gives them a needed opening to discharge their duty to the uncle. In the following lines $(37-51)$ the singers speak as family members themselves: ${ }^{53}$

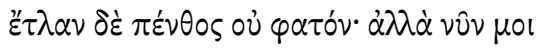

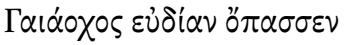

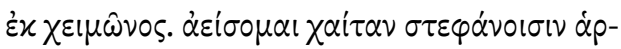

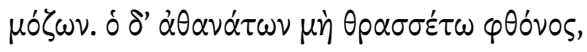

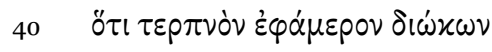

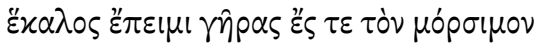

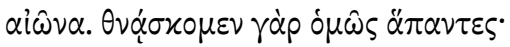

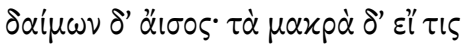

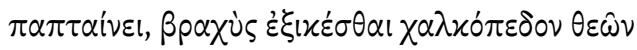

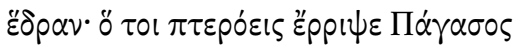

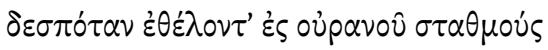

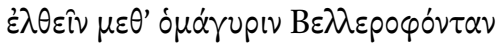

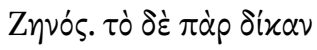

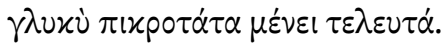

$5^{2}$ I investigate elsewhere the possible generic relationship between the Brothers poem and Pindar's epinician odes.

53 I take the first person in Pindar's odes, when performed, as referring to the performers. For this position see Stehle (1997) 15-17, and for the paeans 127 n. 33 and 139-141. For detailed discussion, see Stehle forthcoming, where I argue on the basis of linguistic analysis, sociology of language, and performance theory that, in the physical presence of a speaker, first-person statements will automatically be attached to him or her by the audience. They can only be deflected when the original speaker or something that represents the speaker is present but needs a secondary voice and is given it by an established practice, e.g., in cases of simultaneous translation or a lawyer reading a will. 


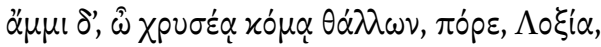

50

$\tau \varepsilon \alpha \hat{\imath} \sigma \iota \nu \dot{\alpha} \mu \dot{i} \lambda \alpha \iota \sigma \nu$

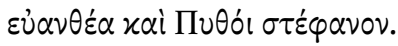

I suffered grief beyond telling, but now

the Earthholder has granted me fair weather

after the storm. I shall fit wreaths to my hair and sing-

may the envy of the immortals cause no disruption.

40 By pursuing the pleasure that comes day by day,

I shall calmly approach old age and my fated

lifetime. For we all alike die,

but our daimōn is unequal. If a man peers at distant

things, he is too little to reach the gods' bronze-paved

dwelling. Indeed, winged Pegasos threw

his master, when Bellerophon desired to enter

the habitation of heaven and the company

of Zeus. A most bitter end awaits

that sweetness which is unjust.

But grant us, O Loxias, luxuriating in your golden hair,

a crown in full blossom

in your contests at Pytho as well.

transl. RACE

In lines $37-39$, which come just after the culmination of their tribute to the uncle at the opening of the third triad, they describe the healing of grief

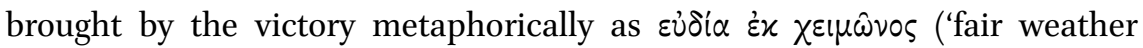
after the storm'). ${ }^{54}$ This eudia, a shared joyful being-at-peace that is based on successful human effort with a god's help, encompasses the whole family group. ${ }^{55}$ Note that having riches is not a basis for eudia; human accomplishment is. ${ }^{56}$

54 Pyth. 5.10-11 has the same image of eudia ek cheimōnos. The word is similarly used in Aesch.

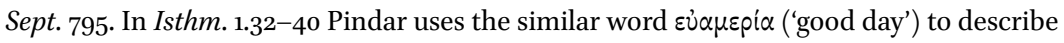
the current good state of the family after a shipwreck. Ol. 1.98 is the only example in Pindar of eudia not used in a context of emerging from troubles.

56 In Pyth.5.10 Pindar comes closer than elsewhere to connecting eudia with wealth when he says that Arkesilas seeks out wealth thanks to Castor, who sheds down eudia on his hearth 
Immediately upon announcing their new songfulness, however, the chorus moves to disclaim any arrogance or greater ambition based on it. Asking that the gods not cut short their joy out of envy, they pledge to pursue the pleasure that each day offers and approach old age and death with calm acceptance.$^{57}$ So eudia brings happiness but requires a modesty befitting mortals to preserve it. They have already attributed their eudia to Poseidon (the god at whose games the victory was won), demonstrating that they recognize his role in Strepsiades' accomplishment.

Between the chorus's proclamation of eudia and the final request to Apollo comes a cautionary meditation on the daimōn. ${ }^{58}$ After the singers acknowledge that we all die, they continue, 'but the daimōn is unequal'. This aphoristic sentence, to judge from what follows, means both that humans receive different life spans as their allotment and that one who seeks more than is allotted to him finds the daimōn punitive, 'not equal' to his desire. ${ }^{59}$ The example illustrating this truth is Bellerophon, the privileged equestrian who thought he could ride Pegasos to Zeus' dwelling on Olympus, by-passing his assigned death, until the divine horse threw him off. Pegasos acted as the daimonn, as

after wintery rain; nonetheless eudia still refers to the victory. This ode is also the only one in which the laudandus himself is called $\mu \alpha \dot{x} \alpha \rho$ ('blessed'), so it is more unqualifiedly flattering than usual.

57 In Ol. 1.97-100 also eudia is combined with the observation that 'the good that comes each day / is greatest for every mortal' and with song. The mortal who wins eudia is contrasted with the hero Pelops, whose tomb is mentioned in the previous lines. The conceptual parallel with Isthm. 7 is striking, so the view of eudia in the latter does not merely reflect a local agenda. See Thummer (1968) 66-68 on these passages.

58 In Pindar, daimōn, in both singular and plural, refers to a range of divine powers from Olympian gods to minor figures who carry out Zeus' will. Once the word is used of a named god (Helios, Ol. 7.39) and once a daimōn gives a pseudonym (Pyth. 4.28-34). Otherwise it signifies nothing more specific than 'divine power' working either good or evil, even though occasionally one can deduce that it refers to the Olympians (e.g., Ol. 1.35). In the singular daimōn is usually an agent but sometimes directed by Zeus; it is often translated as 'fortune', which abstracts too much (but only slightly; cf. Fraenkel [1950] III $63^{2}$ ad $\mathrm{Ag}$. 1341f). In the plural the daimones are either agents or the focus of warnings to speak and act appropriately (aside from two cases in which something affects them, Pyth. 1.12 and Isthm. 8.24). As in Homer it is not a figure to which one could pray; note, e.g., Pyth. 8.6778: the singers pray to Apollo and ask for favor from the theoi for the victor but attribute success without long labor to a daimōn. Obbink (2014) 44 ad 14 takes daimōn in Sappho as 'protective spirit' (and see 43 ad 11), whereas West (2014) 9, who emends (see n. 72 below), translates it as 'fortune'.

'The daimōn is unequal' is followed by 'If one peers at distant things, he is too short to arrive .... The mortal does not measure up to his desired position. 
it were, and caused Bellerophon's end to be one of misery. As in Homer and Hesiod, the daimōn is the face of divinity not receptive to prayer, but hostile to overreaching. ${ }^{60}$

Sappho also uses the image of eudia ek cheimōnos, substituting 'great winds' for 'storm', and the metaphorical meaning found in Pindar makes sense of its appearance in her poem. Eudia is the joyful being-at-peace that Larichos and his family would achieve if he were to follow Sappho's plan and exercise active loyalty (euboulia and aidōs) in the political and/or economic realm as Strepsiades exercised his athletic prowess. ${ }^{61}$ But whereas Pindar introduces eudia achieved, followed by a warning against seeking excess goods that only a daimōn distributes, Sappho is projecting a future eudia, so she first asks Larichos to stop seeking what only the daimōn grants then evokes the possibility of eudia. For Pindar the overreaching involves attempting to escape death, while for Sappho it consists of demanding wealth. ${ }^{62}$ But in both poems if one wishes to enjoy eudia one must renounce a thirst for an excess of good things and focus on the present pleasure that successful human effort brings. ${ }^{63}$

Thus the train of thought articulated by the ráp of Sappho's line 15 must be: let us, being artemess, stop futilely counting on wealth, for joyful beingat-peace can follow. ${ }^{64}$ This is her most powerful plea yet, phrased in vocabulary of the moral good life. ${ }^{65}$ Stanza four includes the three significant terms

6o Very similar to this passage are Pyth. 3.54-6o and Isthm. 5.7-16, both of which mention the daimōn and the limits to what humans should seek.

61 Nünlist (2014) 14 observes that eudia, which he takes as a nautical metaphor, could nonetheless be meant to apply to the 'we' as well as to Charaxos' ship.

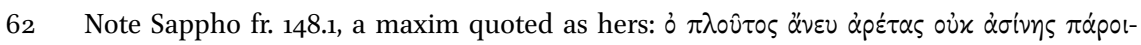
xos ('Wealth without virtue is not a benign neighbor'). Whatever its actual origin, it is compatible with her choice of steadfastness over the fantasy of wealth here. In light of the connections between Sappho and Pindar drawn here, it is worth noting that the line is quoted in scholia to two different passages in Pindar's epinicians. See Voigt ad loc.

63 This is one version of the Pindaric theme of reaching the limit of mortal joy, on which see Thummer (1968) 77-81 for a summary.

64 Most commentators, who take the daimones of line 14 as the (Olympian) gods and eudia as good weather or good fortune, take ráp to mean either that these gods might provide eudia or that eudia is something else that comes by chance (as described in the following stanza). Obbink (2014) 43 suggests both possibilities; Ferrari (2014) 2-3 accepts the first, West (2014) 8-9 the second.

65 The same contrast is found elsewhere in archaic and classical Greek literature, e.g., Solon's contrasting of the life of Tellus with that of Croesus (Hdt. 1.30). 
that form the heart of her solution and her case against Larichos': $\dot{\rho} \tau \tau \varepsilon \dot{\varepsilon} \mu \alpha c$,

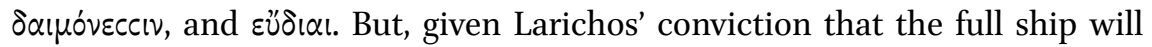
come, mere persuasion is doomed to failure. Even the proffered catharsis and lure of eudia are not attractive as long as he thinks he knows what he will have.

So Sappho tries one more time, with her fourth pairing. But this time her tone changes. Up to this point the poem has been dialogic, with Sappho speaking to Larichos about what she thinks and what 'you' and 'we' should do. The syntax is simple, as befits conversation. First- and second-person forms are abundant. ${ }^{66}$ The last two lines of stanza four (the only general statement in lines $5^{-16}$ ) give a reason for the hortatory subjunctive, so they too are part of the dialogue. The fifth stanza, however, begins with asyndeton, creating a break in the train of thought. ${ }^{67}$ The syntax becomes more complex, beginning with a conditional relative clause with $x \varepsilon^{68}$ There is no first or second person in this stanza. Earlier (6-7), when Sappho says 'Zeus knows' she adds olopal ('I think') to mark her mortal lack of access to the gods, but in stanza five she pronounces without qualification on how Zeus and the daimones function in the divine order. What has happened is that with the asyndeton Sappho gives up the persona of sister and takes on the truth-telling role of a wisdom speaker. ${ }^{69}$ She has reversed roles with Larichos. Early in the poem she criticized him for thinking he could perceive what is known only to the gods because he insisted on the certainty of Charaxos' coming, but now she is the one who can perceive the gods' ways.

Since appreciating the shift of speaking position is important for understanding Sappho's reference to Larichos in the third person in stanza six, I want first to compare it to the partly analogous shift in poem 96 and argue that Sappho does something similar in both poems. The first part of that poem is fragmentary, but editors and text critics agree that there was a second-person pronoun in line 4 , and line 5 clearly contains a second-person adjective: 'and

66 First- and second-person pronouns and verbs appear in lines 4, 5, 6, 7, 9, 13, and 14.

67 On the asyndeton see Obbink (2014) 44; it is rare in Sappho. It could be emended away here, but Obbink, this volume, keeps it. Kurke, this volume, treats it as an explanatory asyndeton, but given the stanza break I think that is problematic. It would be better read as asyndeton that marks a contrast with what went before; see Smyth (1920) at par. 2167d, who remarks that this type is commoner in poetry than in prose.

68 See Lidov ch. 3, this volume, on the rarity of subjunctives, let alone conditions, in Sappho's poetry.

69 Cf. Hes. WD 661-662: (I have little experience of seafaring) 'but even so I will speak the mind of aegis-bearing Zeus, for the Muses taught me to sing an endless song'. 
she delighted greatly in your song.70 The identity of this addressee is not preserved. But the long description of the woman now in Lydia ends (16) with 'and often pacing up and down recalling gentle Atthis with longing, she bites at her tender spirit'. Atthis must be the addressee because the addressee whose singing the other woman so loved then and the one whom that woman recalls now must be the same person. Thus within the dramatic fiction of the poem, Sappho suddenly switches to the third person.

As Leslie Kurke points out, in 96 Sappho shifts the focalization to the thoughts of the woman in Lydia, whereas there is no equivalent signal in the Brothers Poem. ${ }^{71}$ In 96 the focalization is shifted by means of the phrase 'recalling gentle Atthis', where 'recalling' moves the audience into the head of the woman in Lydia. Yet the name Atthis is what makes it noticeable and effective. If Sappho had said 'recalling you' the focalization would be subordinated to the extension of the speaker-addressee relationship produced by the speaker's saying 'you'. Using Atthis' name as the subject of the woman's recollection brings the relationship between Atthis and the woman in Lydia to the fore in its place (and serves as a kind of seal on it for the actual audience).

In the Brothers Poem the change of focalization is not from one person to another but from one persona to another. Up to the end of the fourth stanza Sappho has been speaking as a sister, initially critical but increasingly cajoling as she addresses Larichos from a stance that acknowledges his greater power. When she shifts to a wisdom-speaker's position her focalization changes to that of a superordinated observer. As a result, no single verb can accomplish the change as in 96 ; it must be enacted by demonstrating the new perspective, which is what stanza five accomplishes. But, just as in 96 , the speaker in this poem drops the I-you interchange to allow a new relationship, not subordinated to the relationship already established, to come to the fore. In this case, the new relationship is one of detachment on the speaker's part, which she later confirms by referring to Larichos by name in the third person.

Now we can look more closely at the last two stanzas. In her final pairing Sappho does not introduce a new set of considerations but expands on the

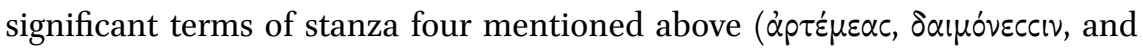
$\varepsilon \mho \tilde{\delta}(\alpha \iota)$ by unfolding what they mean for Larichos' case. Each of the first two takes a full stanza and sets out a comprehensive vision of its implications. But

$70 \quad$ See Voigt ad loc, Page (1955) 89, 92 for the pronoun in line 4.

$71 \quad$ Kurke, this volume. I thank her for letting me see her comments, which have forced me to think through my argument more thoroughly. 
because her stance is now didactic rather than persuasive she no longer speaks of desired outcomes but rather of cause and effect: each stanza contains a conditional clause stating the relationship.

In stanza five, Sappho describes the role of the daimon in the cosmic distribution of wealth: 'the ones whose daimōn Zeus directs to divert (them) as helper away from troubles, $x$ iv $0 \mathrm{or}$ (those people at a distance from the speaker) become blessed and very rich. ${ }^{72}$ The daimōn here plays a positive role as opposed to its negative one in Isthmian 7 , but for $x$ îvol, who are elsewhere. Sappho's statement therefore comes to the same thing as Pindar's aphorism, 'the daimōn is unequal': mortals have no sure way to predict, let alone bring about, their own extraordinary well-being. Sappho's $\mu \alpha \dot{\alpha} \alpha \rho$ ('blessed'), a strong term most often applied to the gods or to epic heroes, indicates the special, almost mythic bliss of those so favored. ${ }^{73}$ This 'truth' explains her urging Larichos in line 14 to relinquish all else to the daimones. By spelling it out Sappho effectively overrides Larichos' statement of certainty about Charaxos' bringing home a full ship: Larichos may think that, with Charaxos' ship as his Pegasos, he can get to that happy condition by willing it, but like Bellerophon he is deluded.

Stanza six brings the new perspective down to earth: 'And we too, if Larichos lifts his head and really one of these days $\left(\pi \circ \tau^{\prime}\right)$ becomes a man, would indeed immediately be released from great heavy-heartedness'. The stanza opens with a first-person-plural pronoun $(\varkappa \ddot{\alpha} \mu \mu \varepsilon c)$ that makes it look for a moment as though Sappho is returning to the I-you form of discourse. It also resonates with $x$ ฑ the opening of the fifth stanza (note $x \varepsilon$ in 17 and 21), thus creating a momen-

72 I take daimōn, plural in 14 and singular in 18 , to refer to the same kind of divine powers. West (2014) 9 suggests an emendation in line 18 ('toward the better' to replace 'helper') that makes the syntax easier and translates daimōn in 18 as 'fortune'. See Lidov, ch. 3, this volume for objections. Obbink (2014) 44 objects that it gives a different sense for daimōn from that in line 14. (West and Ferrari [2014] 3 do not see that as a problem.) It also seems to me possible to keep 'helper' and still take the infinitive $\pi \varepsilon p \tau p o ́ \pi \eta v$ as either activetransitive or passive-intransitive; see Voigt 208 CRIT ad Alc. 70.9. If it is passive-intransitive the syntax is similar to what West suggests except that $\dot{\varepsilon} \pi \dot{\alpha} \rho \omega \gamma o v$ is then proleptic ('change direction [so as to be] a helper').

$73 \mu \alpha \dot{x} \alpha \rho$ is very seldom used in Homer and Pindar of living humans. In Homer only Agamemnon receives the adjective (Il. 3.182): Priam calls him that in an apostrophe, together

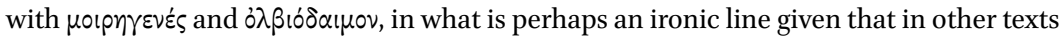
both of them suffer the same fate of being killed at the altar in their own homes. In Pindar Arkesilas is $\mu \dot{\alpha} x \alpha \rho$ (Pyth. 5.20), as is his hearth (Pyth. 5.11), and his charioteer is $\mu \alpha x \alpha \dot{p}$ los (Pyth. 5.46). Hieron only has a 'blessed hearth' (Ol. 1.11). 
tary impression that Sappho might say something on the order of 'we, like those people, if Zeus favors us, may become blessed'. But that is not how it unfolds. She says nothing about gods or divine helpers. Instead, the momentary misdirection gives the following words more impact because they are unexpected: humans, in the person of Larichos, must create by their own actions a limited but more lasting happiness by collaboration with their communities.

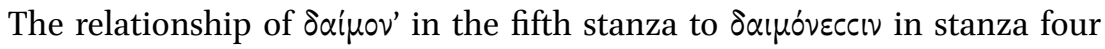
is clear from the repetition of the noun. But Sappho takes care to emphasize the less obvious link between stanza six and artemeas and eudiai in the fourth stanza by parallels. Both four and six begin with a form of the pronoun 'we':

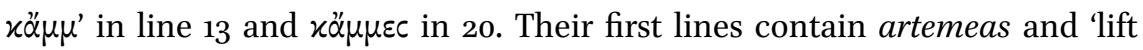
his head' respectively. The third and fourth lines of the respective stanzas are 'for eudiai out of great winds / immediately arise' and 'out of very great heavyheartedness / immediately we would be released'. Great winds align with heavyheartedness, and the rise of eudia aligns with being released. 'Immediately' at the beginning of the last line of each stanza reinforces the parallel between eudia and release from dejection.

To confirm from another direction that the phrases 'lift his head' and 'become a man' refer to and define what Sappho means by artemēs, we can look to Homer and Pindar again. Pindar uses the phrase 'lift his head' in Paean 20 to describe the baby Heracles' response to the two snakes sent by Hera to kill him $(7-12)::^{74}$

ö $\varphi$ ६६ $\theta \varepsilon \dot{\pi} \pi \circ \mu \pi[01 \quad]$

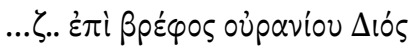

10

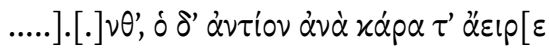

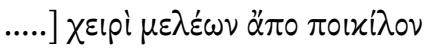

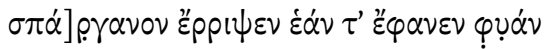

.... ] through the doors

the heaven-sent snakes[

...] toward the child of heavenly Zeus

10

..... but he was lifting up his head to face them

..... ] with his hand he threw from his limbs the elaborate

swaddling cloth and revealed his natural force ...

transl. RACE

74 Rutherford (2001) 399-402 classifies it as a dubious paean. 
The action of lifting his head shows that Heracles notices their coming and recognizes the danger. He immediately prepares to confront them by throwing off his bedclothes. By analogy, Larichos' lifting his head would mean seeing the situation clearly and recognizing that he had to act. ${ }^{75}$

Parallels with 'become a man' are found in the Iliad, for instance at 5.529, in the same scene in which Aeneas returns to battle artemea. Agamemnon ranges through the ranks exhorting, ' $\mathrm{O}$ friends, be men and take on a stout heart!'

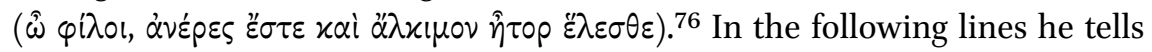

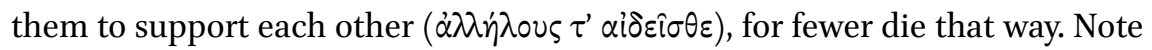
the resonance between his speech and Sappho's wish that 'Charaxos find us artemeas. ${ }^{\prime 7} \mathrm{~A}$ parallel that is more distant in time but closer in circumstance is found in Euripides' Electra. Electra tells Orestes that if he dies in the attempt to kill Aegisthus she will die also. When he replies that he understands, she adds

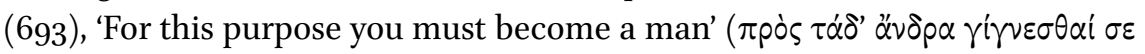
$\left.\chi p \eta^{\prime}\right)$. She means, as the context shows, 'you must exercise manliness for the sake of us both'.

Thus Sappho uses the two phrases 'ift his head' and 'become a man' precisely to indicate the qualities that Larichos needs to become artemēs. The combination makes it clear that they do not refer to a process of growing up. ${ }^{78}$ Scholars have compared Larichos to Telemachos in the Odyssey, but I would suggest

75 West (2014) 9 comments that Larichos 'remains inert and submissive'. I disagree with the 'submissive', but 'inert' seems right. Liberman (2014) 1 takes the two phrases in combination in a moral sense; Larichos should 'affronter la situation difficile'.

76 The phrase 'be men' also occurs together with the half-line 'and put fear-of-shame (aidōs) into your spirit' at $I l$. 15.561. A slight variant is found seven times with the half-line 'and remember impetuous courage'. See Kirk (1990) ad 528-532.

$77 \alpha \dot{\alpha} \eta \dot{p}$ does not seem to carry the connotation of adult man as opposed to youth in early Greek. In both Homer (e.g., Il. 23.589, Od. 3.24) and Pindar (e.g., Ol. 4.25-26; 13.23) youths

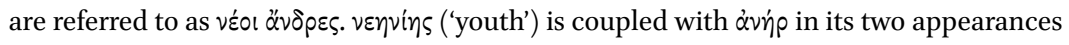
in Homer $(\mathrm{Od}$. 10.278, 14.524). Two passages in the Odyssey contrast someone's being an $\alpha \nu \eta \dot{\rho}$ with that person's previous state, but neither is about the difference in age between a man and a youth. In 11.448-450 the son who is now an $\alpha \dot{\nu} \rho$ was then a baby at the breast. In 19.160-161 Penelope says of Telemachus that 'he is now a man capable of caring for a household, and Zeus gives him glory'. This reflects Telemachus' recent demonstrations of independence and initiative, rather like what Sappho hopes to see from Larichos, as much as his change in chronological age.

78 Martin, this volume, refers to $\mathrm{Il}$. 10.77-85, where depiction of Nestor raising his head to greet Agamemnon in the middle of the night is preceded by five lines describing his armor close by in order for battle. Nestor is 'ready'. 
Paris in the Iliad as the better parallel. ${ }^{79} \mathrm{Or}$, to return one last time to Isthmian 7 , Pindar's Bellerophon and Strepsiades give us a model for Sappho's view of Larichos: he should be less like Bellerophon, trying to acquire what mortals cannot expect, and more like Strepsiades, who brings eudia to the whole family by his successful effort.

Stanzas five and six also reverse the order in which Sappho introduces daimones and artemēs in stanza four. In her persuasive mode she is trying to move Larichos bit by bit toward collaboration with the family so that his singular focus on the cargo dissipates, so her most direct suggestion that he abandon it (14) comes last. In stanzas five and six she first points out the 'truth' about the allocation of wealth as the reality to which Larichos must adapt and then outlines the path he must follow if the family is to achieve lightness of heart. So whether Larichos is included in or excluded by the 'we' that opens the stanza is an open question, for it depends on whether Sappho's final description of his place in the cosmos penetrates his defences, whether he changes his attitude and rejoins the family as a constructive member of it. Sappho leaves it up to him, and each listener could decide for herself how it plays out. Thus the poem is not really about wealth per se but about acting rather than assuming the gods' favor.

This brings me back to familial gender dynamics. Sappho gives us a miniature drama of a sister trying to persuade her brother to face a threat to family well-being and respond with action. The only direct criticism of the brother's current behavior is the accusation in the second stanza that he 'insists on' something that it is not his place to assert. Then she tries to convey to him what she expects of him by previewing the prayer she wants to make, for prayer is one form of discourse that was legitimate for women. She urges him to join her in entrusting 'all the rest' to the daimones without mentioning wealth and making it a family commitment rather than her advice for him. But since these strategies are not powerful enough to penetrate the shield of certainty that he wraps around himself, she finally adopts a speaking style that is encoded with greater authority, that of wisdom-poet, establishes her new persona by explaining cosmic daimonic action, then describes Larichos with 'truth' as an object of her observation. She turns the tables on Larichos, trumping his certainty by her broader purview. The eudia that in Pindar's odes celebrates victors is represented in the last stanza by its opposite in order to highlight Larichos' failure. That he is not an $\alpha \dot{v} \dot{p}^{\circ}$ ('man') in the Iliadic sense is her crowning insult. She

79 See $I l \cdot 3 \cdot 3^{8}-57$ for Hector's criticism of Paris. Martin, this volume, among others, adduces Telemachus. 
is dubious that he will be able to implement her solution: note $\pi \circ \tau$ ' ('one of these days') and the optative $\lambda \dot{v} \theta \varepsilon \mu \varepsilon \varepsilon$ ('we would be released') in place of the indicative in stanza six.

For the actual audience, the switch to the third person in line 22 must have been both a surprise and a pleasure. Since they had been hearing Sappho address Larichos for four stanzas he was present to their imaginations, so they would easily recognize that Sappho's change of perspective allowed her to view him from above, so to speak, and finally say what they must have suspected she meant. They now get a clearer picture of Larichos and deeper insight into Sappho's motivation for her persuasive effort. Her using the third person to demote him would spark their enjoyment of the revenge Sappho takes on this fictional paradigm of a feckless brother. ${ }^{80}$ The final stanza must have elicited laughter.

Yet her final lines also convey a recognition that for all her poetic power she remains a woman dependent on the male members of her family. The optative $\lambda \dot{\theta} \theta \varepsilon \mu \varepsilon v$ in place of the earlier indicative acknowledges that Sappho's release from dejection relies on the actions of her male kin; it is not something that she can bring about for herself. The poem is only fictional revenge, born of the double consciousness that Jack Winkler saw in Sappho's poetry and admitting the impossibility of the power Sappho briefly arrogates to herself in her Hesiodic guise. ${ }^{81}$ Thus the laughter is in the face of a reality that the women cannot change. ${ }^{82}$

Athenaeus says that Sappho praised Larichos in many passages for pouring wine in the town council of Mytilene. ${ }^{83}$ That does not preclude her from criticizing him in other poems depending on the relationship she wants to explore through her fictions. Sappho's critical depiction of Larichos here could have been paired with a rebuke of Charaxos: Larichos loves the leisure of the symposium and does not support the family fortunes, while Charaxos ventures out to gain merchandise and slights his sister (5.9-10). One might even imagine that in Sappho's series of 'brothers poems' a poem about Charaxos and

8o Martin, this volume, interprets this stanza as iambic, a genre of criticism and mockery.

$81 \quad$ Winkler (1981), esp. 68-71.

82 Neri (2015) $67 \mathrm{n}$. 103 suggests that my reference to laughter ignores the urgency of the situation. Since the situation is a fiction (in my view), its urgency is an artifact of the poem, but that the poem addresses real difficulties for women I agree, and the laughter is also acknowledgement of them.

83 Athenaeus 10, 425a = test. 203a. 
the courtesan, as described by Herodotus, followed this one. ${ }^{84}$ If so, Larichos' fantasy ends badly, for Charaxos would not have brought home wealth on that occasion.

84 Lidov 2002 shows that this episode developed a variegated life as a pastiche. But the new poem gives more substance to the idea that Sappho referred to what (a fictional) Charaxos brought home, so it is not implausible that in one of her brothers poems Sappho took Charaxos to task for his dereliction as a trader. That would be enough of a hook to attract other stories. The Posidippus poem that Lidov (idem: 222) mentions does not show that Sappho praised Doricha but only that Sappho mentioned her and so immortalized her name. 